\title{
SEVERAL SPECIFICATIONS CONCERNING THE PROBLEM OF THE CALENDAR
}

\author{
Ph.D. Marian VîLCIU, \\ Faculty of Orthodox Theology and Education Sciences, "Valahia" University, Târgovişte, \\ Faculty of Orthodox Theology, Doctoral School of Theology, \\ University "1 Decembrie 1918" Alba Iulia, \\ ROMANIA, \\ E-mail: mvilciu@yahoo.com
}

\begin{abstract}
Since the very beginnings of his existence, mas was preoccupied by this phenomenon, and even if time is an abstract concept, as it can't be divided, there was the preoccupation for a certain concretization of time, a system of measurement, so that, according to this periodization, man would be able to manage and unfold his social, material and religious life. This is why, from the most ancient times, men directed their attention towards different changes and phenomena of nature and, respecting the Holy Bible, they observed especially the astronomical phenomena.
\end{abstract}

Keywords: Christian; calendar; Sosigene; Gregorian reform;

\section{INTRODUCTION}

The theology of the Orthodox Church shows us that ,the world was not created in time, but in the same time with time", therefore understanding that time, as well as space, represents a dimension of the existence. In other words, man's life, between his two worldly limits, life and death, unfolds in time. Since the very beginnings of his existence, mas was preoccupied by this phenomenon, and even if time is an abstract concept, as it can't be divided, there was the preoccupation for a certain concretization of time, a system of measurement, so that, according to this periodization, man would be able to manage and unfold his social, material and religious life. This is why, from the most ancient times, men directed their attention towards different changes and phenomena of nature and, respecting the Holy Bible, they observed especially the astronomical phenomena.

\section{THE FIRST CHRISTIAN CALENDAR}

The very first pages of the Old Testament show us that: „And God said, $<<$ Let there be lights in the vault of the sky to separate the day from the night, and let them serve as signs to mark sacred times, and days and years, and let them be lights in the vault of the sky to give light on the earth.>> " (Genesis 1, 14-15), men have attempted to establish different methods to measure time, thus appearing the issue of the calendar.

The word calendar has Latin etymology, deriving from the word calendae (which, at its turn, has the etymology in the Greek word $\kappa \alpha \lambda \tilde{\omega}=$ to summon, to convoke), which indicated the Roman's practice of summoning all the citizens in the forum, in the first day of each month, in order to be informed about various issues of the community. Unlike the Romans, the Greeks didn't have among their social practice such summoning, a thing that made possible the appearance of the expression ,at the Greek calendae”, that meant that a promise, once made, was never to be fulfilled. 
Therefore, the first calendars appear out of the man's desire and need to establish in time the religious events and feasts and to organize as best as possible his daily occupations and chores. In order to do this, it was enough to direct his attention towards the sky, towards the sun, the great luminary of the day and towards the moon, the night luminary. The observation of nature gave him the possibility to discover the first time unit, about which the first pages of the Holy Bible also speak: „And there was evening and there was morning: the first day" (Genesis 1, 5).

Man was able to observe that day and night succeed one another with rhythmicity, thus representing a very handy unit of time measurement. This is why since the most ancient times man chose as medium unit of time measurement the average solar day, which represents the time that earth needs to make a complete rotation around its axis. In the same time, there were established the multiples and submultiples of the solar day: the Hours with minutes and seconds: the day has 24 hours, the hour-60 minutes, the minute- 60 seconds; the Week, namely the span of time that the moon needs to pass through its two consecutive phases (approximately 7 days); the monthly Moon, which represents the period of time that the moon needs to make a complete rotation around earth, a movement which takes 29 days and a half (more precisely 29 days, 12 hours, 44 minutes and 2,9 seconds); the tropical Year, also called the solar, or astronomical year, namely the period of time the earth needs to make a complete rotation around the sun, a period which represents approximately 365 days and 6 hours (more precisely 365 days, 5 hours, 48 minutes, 45-46 seconds) ${ }^{1}$.

Because of the fact that the tropical, solar or astronomical year doesn't have a precise number of days, it could not have been taken as a unit of time measurement, which is why there was the need to make a conventional unit of time, starting from the tropical or astronomical year, to which was added the fraction of one day, this conventional unit of time measurement being the calendar or civil year. The latter did not coincide as extension, as length, with the astronomical year, which is why men have searched that, from time to time, by using various methods, to ensure a most faithful coincidence between the two units of time measurement, concerning their extension. Thus appeared what we know as the calendar problem, namely the preoccupation which has as purpose the discovery of the best method by which the civilian or calendar year to be as close as possible, as duration, to the astronomical or tropical one.

If the most ancient peoples used monthly calendars, namely those instruments of time measurements based on the rotation movement of the moon around the earth (the first Egyptian calendar, the Greek or Roman calendars), others have used mixed calendars, lunarsolar ones (like in the Hebrew's case), the first who made and used a solar calendar, based on the Earth's revolution movement, were the Egyptians, the calendar being undertaken by the Romans and improved by them under the form of the Julian calendar, which stands at the base of the modern chronology ${ }^{2}$.

\section{HISTORY OF CHRISTIAN CALENDAR}

The calendar used today worldwide has a long and, might we say, interesting history. Its inceptions are connected to the Roman Empire, its construction being initiated by the Roman emperor Julius Caesar (100-44 B.C.), who, in the year 46 B.C., asked the Alexandrine astronomer Sosigene to make a thorough system of time measurement, which

\footnotetext{
1. See Pr. Prof. Dr. Ene Branişte, Liturgica Generală, Ed. Episcopiei Dunării de Jos, Galaţi, 2002, p. 104;

2. Cf. Dr. Vasile Gheorghiu, Noţiuni de cronologie calendaristică şi calcul pascal, Tipografia Cărţilor Bisericeşti, Bucureşti, 1936, pp. 23-26;
} 
he did, using all the astronomical and scientific data encountered in those days in the famous cultural center of Alexandria. Thus, Sosigene set the bases of a scientific solar calendar, based on the apparent movement of the sun in the sky and also considering the movement of the other celestial corps. This calendar, make at the Emperor Julius Cesar's request, was obviously named after the emperor's name, being known as the Julian calendar.

Sosigene, knowing the exact duration of the tropical, solar or astronomical year, had to align this duration with that of the civilian or calendar year, thus establishing the duration of the later to 365 days. As aforementioned, the astronomical year is longer than the calendar one with approximately 6 hours (more precisely 5 hours, 48 minutes, $45-46$ seconds), which is why the astronomer Sosigene, in order to ensure the concordance between the astronomic year and the calendar one, has established to add one day a year once every four months $(6 \mathrm{x}$ $4=24$ hours, which is one day), so that, every four years, the civil year has 366 days, being named bissextile year.

In the same time, Sosigene maintained the partition of the year into 12 months, but their duration had no connection whatsoever with the movement of the moon on the sky, thus being simple divisions or arbitrary units of time measurement. It just so happens that, conventionally speaking, some months have 30 days, others 31 days, while February had 28 years in the usual years (of 365 days), and 29 days in the bissextile years. The inventor of the calendar established the spring equinox (the data at which the duration of the day is equal with the duration of night) at 24 March, and the beginning of the year at 1 March, this fact reminding us the names of the autumn months, September, namely the seventh month, October, the eight month etc. But not after long the beginning of the churchly year was moved for the $1^{\text {st }}$ of January.

The calendar that Sosigene made and was used throughout the Roman Empire was undertaken and used by the Christians also, introducing in it specific Christian celebrations.

Apparently, the calendar made by Sosigene the Alexandrine, was to ensure the concordance between the astronomic year and the calendar one (the latter having 365 days and 6 hours), but, as it was an approximation to 6 hours, the difference between the astronomic and the calendar years being actually 5 hours and 48 minutes and 45-46 seconds, the difference of 11 minutes and 14-15 seconds, determined by the approximation, was not under the incidence of the calendar calculus, being thus neglected. Because of this small difference, which was imperceptible in a generation, once every 128 years the calendar year fell behind the astronomic one with one day ${ }^{3}$.

This situation was observed at the first Ecumenical Synod from Constantinople (325), when they observed that the spring equinox, established by Sosigene at $24^{\text {th }}$ of March, fell, at the beginning of the $4^{\text {th }}$ century, on the $21^{\text {st }}$ of March. The fathers who took part at this synod, dealing among others with the Easter celebration either ${ }^{4}$, after observing these realities, they decided that from that moment on the spring equinox to remain on $21^{\text {st }}$ of March, without taking further measures so that the date will not be changed again in the future. In the same time, the first Ecumenical Synod decided that the Easter Day to be celebrated always on Sunday, the Sunday that would follow the first new moon after the

\footnotetext{
3. Ibidem, pp. 28-30;

4. Pr. Prof. Ioan Rămureanu, Arianisnul. Sinodul I ecumenic de la Niceea din 325, in Istoria Bisericească Universală, vol. I, Editura Institutului Biblic şi de Misiune al Bisericii Ortodoxe Române, Bucureşti, 1993, p. 319;
} 
spring equinox. If this day was to coincide with 14 Nisan (the Hebrews' Easter), the Easter was to be celebrated in the following Sunday 5 .

In this situation, as no correction measures were taken for the calendar calculus deficiency, the difference between the astronomic year and the calendar one continued to increase with one day once every 128 years, and because of this thing, at the beginning of the $16^{\text {th }}$ century, the spring equinox fell 10 days later than the normal data, which determined an erroneous data for the Easter Day.

The $16^{\text {th }}$ century brought an improvement for the concordance between the astronomic and the calendar year. In the second half of this century was observed that the calendar year fell behind the astronomical one with 10 days, while the spring equinox didn't fell on the $21^{\text {st }}$ of March, but on the $11^{\text {th }}$ of March. In these conditions, ever since the Tridentine Synod (1545-1563) ${ }^{6}$ was considered this calendar problem, with the purpose of being solved, and was therefore decided to make a commission which to study the problem and to propose actual measures for solving it. Under the direct coordination of Pope Gregory XIII, this commission, which included the Italian astronomer Luigi Lilio, elaborated a reformation report, evaluated and approved by the most important astronomers of those times: the German Christophor Clavius (a Jesuit priest), the Spanish Peter Ciaconus and the Italian Ignazio Danti ${ }^{7}$. Following this report, in 1582, Pope Gregory XIII, gave the bulla Inter gravissimas, making a correction of the Julian calendar. It was thus decided to remove the 10 days with which the calendar year was behind the astronomic one, the date of 4 October 1582, becoming 15 October. Moreover, the spring equinox was once again established on the $21^{\text {st }}$ of March, just like it was in the times of the first Ecumenical Synod, establishing different measures which to ensure the congruence between the astronomic year and the calendar one for a longer period of time, approximately 3400 years. Regarding the centenary bissextile years $(1600,1700,1800$ etc.) bissextile remained only those which perfectly divided to four, while the others remained common years, in other words of 365 days. In the same time, they decided that, if the astronomical realities should ask for it, the extra day of a bissextile year to be cut off with the purpose of ensuring the congruence between the astronomic and the civil year ${ }^{8}$.

The process of correcting the calendar, initiated by Pope Gregory XIII is known in the history of the Church under the name of the Gregorian reform. We agree with this entitlement, and we disagree with the usage, which we consider erroneous, of the expression the Gregorian calendar, because Pope Gregory XIII did not make a new calendar, but he initiated and developed a reformation of the Julian calendar, which is we consider the Gregorian reform as being more suited.

This calendar, corrected by the Gregorian reform, begun to be used by the western Catholic Church, while the protestant churches refused to accept it out of confessional raisons. Later on, starting with the first years of the $18^{\text {th }}$ century, the protestant states, reaching the conclusion that the calendar reformation is justified by scientific-astronomic raisons, begun to adopt and use it.

\footnotetext{
5. For details see T. M. Popescu, Problema stabilizării datei Paştilor. Privire istorică asupra divergenţelor şi computurilor pascale, in Ortodoxia, XVI (1964), no. 3, p. 430;

${ }^{6}$. Pr. Prof. Ioan Rămureanu, Pr. Prof. Milan Şesan, Pr. Prof. Teodor Bodogae, Istoria Bisericească Universală, vol. II, Editura Institutului Biblic şi de Misiune al Bisericii Ortodoxe Române, Bucureşti, 1993, pp. 229-232;

${ }^{7}$. Dr. Vasile Gheorghiu, op.cit., p. 50;

${ }^{8}$. See Pr. Prof. Dr. Ene Branişte, op. cit., p. 106;
} 
Pope Gregory XIII send a letter to the Eastern Church, requesting the recognition of the calendar reformation and its introduction in the Church's life. Patriarch Jeremiah II of Constantinople send a response letter to the pope, in August 1583, in which he explains that the pope's request cannot be respected because the demarche that was initiated by the papacy was not prefaced by an understanding with the Eastern Church, and an application of the reformed calendar would arise discontentment among the Orthodox faithful ${ }^{9}$, which is why the Eastern Church will continue to use the old calendar.

For almost 350 years, the Christendom was divided, as far as the calendar was concerned, in two great parts: the western Church which used the calendar corrected by the Gregorian reform, also called the new style, and the eastern Church which used the Julian calendar, also called the old style. This reality maintained until the beginning of the $20^{\text {th }}$ century, when the Orthodox Church was forced by the options of some orthodox states, which adopted the reformed calendar in the public, civilian life (Bulgaria, Russia in 1918, Serbia and Romania in 1919, Greece 1923), to show a special attention to this issue and to seek solution for solving it.

In 1923, at Constantinople was organized an inter-orthodox Congress, at which was decided the correction of the Julian calendar for all the Orthodox Churches. As a procedure, were removed the 13 days with which the calendar year fell behind the astronomical year, bringing once again the spring equinox from 8 March (as it was in 1923) to 21 March. Furthermore, based on the new scientific and astronomic discoveries, was established a new system of calculating the bissextile years, far superior to the one applied by the Gregorian reform, which was meant to ensure the congruence between the calendar year and the astronomic one for a much longer period of time, of approximately 44.000 years. In the same time, the Congress allowed the autocephalous Orthodox Churches to apply the decisions adopted at this assembly, for the moment at which the socio-political and religious conditions of each national Orthodox Church will be favorable for such a demarche.

After 1923, nearly all the autocephalous Orthodox Churches begun to adopt the reformed calendar and to introduce it in their cult, and today only the Patriarchy of Jerusalem, the Russian Church, the Serbian Church and the monasteries from Mount Athos are still using the Julian calendar, a reality that created a new problem amongst the Orthodox Churches.

\section{CONCLUSIONS:}

Considering that the aforementioned Orthodox Churches did not adopted in their liturgical life the reformed calendar, the Orthodox Churches that use the new style calendar were forced, by raisons of brotherly communion, to celebrate Easter and the other feasts connected to it, according to the old Pascaly, so that all the Orthodox Churches to celebrate altogether the greatest Christian celebration, the Easter ${ }^{10}$.

Alas today the Christendom is divided into three parts by the calendar used in the liturgical life:

1. The western Church which uses the reformed calendar, also called the new style;

\footnotetext{
9. See C. Popovici, Capitolul al şaptelea al literei P din sintagma alfabetică a lui Mateiu Vlastaris: Despre Sfintele Paşti sau Despre computul pascal, Cernăuţi, 1900, p. 317 ş.u.;

10. Pr. Prof. Dr. Nicolae D. Necula, Este posibilă şi necesară serbarea Paştelui din anul 2000 in aceiaşi zi cu Bisericile apusene, in Tradiţie şi înnoire în slujirea liturgică, vol. II, Ed. Episcopiei Dunării de Jos, Galaţi, 2001, pp. 182-183;
} 
2. The Orthodox Churches that still use in their cult the Julian calendar, also called old style (the Patriarchy of Jerusalem, the Russian Church, the Serbian Church and the monasteries from Mount Athos);

3. An intermediary position is occupied by the Orthodox Churches that have adopted the reformed calendar, according to the recommendations made by the InterOrthodox Congress of Constantinople from 1923, also called new style, churches that used a mixed calendar: for the feasts with fix data they used the reformed calendar, while for feasts with changing date (Easter and the other feasts determined by it) they use the old Pascaly, as a concession made to the Orthodox Churches that have not yet adopted the reformed calendar.

Thus stands the situation which exists nowadays in the Christian world, as far as the use of calendar in the liturgical life of the Christian Churches is concerned, a situation that arise plenty of question marks amongst the faithful. This situation can only be solved in a single manner, namely the adoption of the reformed calendar, the new style, by the other Orthodox Churches also, which up until now haven't find a favorable moment to adopt this calendar, despite the fact that it was demonstrated that the old style one does not longer correspond to the astronomical reality. In the same time, we have to say that this system of time measurement is a conventional instrument, which is meant to ensure an optimal environment for man's religious and social life, as the calendar is not a dogma, and adopting the reformed calendar doesn't mean a a defection or deviation from the Orthodox traditions, a fact which, alas, was not understood by all the Orthodox Churches.

\section{BIBLIOGRAPHY:}

[1] Dr. Vasile Gheorghiu, Noţiuni de cronologie calendaristică şi calcul pascal, Tipografia Cărţilor Bisericeşti, Bucureşti, 1936

[2] Pr. Prof. Dr. Ene Branişte, Liturgica Generală, Ed. Episcopiei Dunării de Jos, Galaţi, 2002

[3] Pr. Prof. Ioan Rămureanu, Arianisnul. Sinodul I ecumenic de la Niceea din 325, in Istoria Bisericească Universală, vol. I, Editura Institutului Biblic şi de Misiune al Bisericii Ortodoxe Române, Bucureşti, 1993

[4] T. M. Popescu, Problema stabilizării datei Paştilor. Privire istorică asupra divergenţelor şi computurilor pascale, in Ortodoxia, XVI (1964), no. 3

[5] Pr. Prof. Ioan Rămureanu, Pr. Prof. Milan Şesan, Pr. Prof. Teodor Bodogae, Istoria Bisericească Universală, vol. II, Editura Institutului Biblic şi de Misiune al Bisericii Ortodoxe Române, Bucureşti, 1993,

[6] C. Popovici, Capitolul al şaptelea al literei P din sintagma alfabetică a lui Mateiu Vlastaris: Despre Sfintele Paşti sau Despre computul pascal, Cernăuţi, 1900,

[7] Pr. Prof. Dr. Nicolae D. Necula, Este posibilă şi necesară serbarea Paştelui din anul 2000 în aceiaşi zi cu Bisericile apusene, in Tradiţie şi înnoire în slujirea liturgică, vol. II, Ed. Episcopiei Dunării de Jos, Galaţi, 2001 